\title{
Impact of reduced anthropogenic emissions during COVID-19 on air quality in India
}

\author{
Mengyuan Zhang ${ }^{1}$, Arpit Katiyar ${ }^{2}$, Shengqiang Zhu ${ }^{1}$, Juanyong Shen ${ }^{3}$, Men Xia ${ }^{4}$, Jinlong Ma ${ }^{1}$, Sri Harsha Kota ${ }^{2}$, \\ Peng Wang ${ }^{4}$, and Hongliang Zhang ${ }^{1,5}$ \\ ${ }^{1}$ Department of Environmental Science and Engineering, Fudan University, Shanghai 200438, China \\ ${ }^{2}$ Department of Civil Engineering, Indian Institute of Technology, Delhi, 110016, India \\ ${ }^{3}$ School of Environmental Science and Engineering, Shanghai Jiao Tong University, Shanghai 200240, China \\ ${ }^{4}$ Department of Civil and Environmental Engineering, The Hong Kong Polytechnic University, \\ Hong Kong SAR, 99907, China \\ ${ }^{5}$ Institute of Eco-Chongming (IEC), Shanghai 200062, China
}

Correspondence: Peng Wang (peng.ce.wang@polyu.edu.hk) and Hongliang Zhang (zhanghl@fudan.edu.cn)

Received: 28 August 2020 - Discussion started: 9 October 2020

Revised: 8 February 2021 - Accepted: 8 February 2021 - Published: 17 March 2021

\begin{abstract}
To mitigate the impacts of the pandemic of coronavirus disease 2019 (COVID-19), the Indian government implemented lockdown measures on 24 March 2020, which prohibited unnecessary anthropogenic activities, thus leading to a significant reduction in emissions. To investigate the impacts of this lockdown measure on air quality in India, we used the Community Multi-Scale Air Quality (CMAQ) model to estimate the changes of key air pollutants. From pre-lockdown to lockdown periods, improved air quality is observed in India, indicated by the lower key pollutant levels such as $\mathrm{PM}_{2.5}(-26 \%)$, maximum daily $8 \mathrm{~h}$ average ozone $\left(\mathrm{MDA} 8 \mathrm{O}_{3}\right)(-11 \%), \mathrm{NO}_{2}(-50 \%)$, and $\mathrm{SO}_{2}(-14 \%)$. In addition, changes in these pollutants show distinct spatial variations with the more important decrease in northern and western India. During the lockdown, our results illustrate that such emission reductions play a positive role in the improvement of air quality. Significant reductions of $\mathrm{PM}_{2.5}$ concentration and its major components are predicted, especially for secondary inorganic aerosols that are up to $92 \%$, $57 \%$, and $79 \%$ for nitrate $\left(\mathrm{NO}_{3}^{-}\right)$, sulfate $\left(\mathrm{SO}_{4}^{2-}\right)$, and ammonium $\left(\mathrm{NH}_{4}^{+}\right)$, respectively. On average, the MDA8 $\mathrm{O}_{3}$ also decreases $15 \%$ during the lockdown period although it increases slightly in some VOC-limited urban locations, which is mainly due to the more significant reduction of $\mathrm{NO}_{x}$ than VOCs. More aggressive and localized emission control strategies should be implemented in India to mitigate air pollution in the future.
\end{abstract}

\section{Introduction}

India, the second-most populous country in the world, has been suffering from severe air pollution along with rapid urbanization and industrialization in recent decades (Karambelas et al., 2018), and 13 Indian cities were among the world's top 20 most polluted cities according to the World Health Organization (WHO) (WHO, 2018). High-level pollution leads to health risks and ecosystem damage, which caused 1.24 million deaths in India in 2017 (Balakrishnan et al., 2019) and a great loss of crops (Oksanen et al., 2013; Lal et al., 2017). To mitigate air pollution, the Indian government has been promoting effective emission control strategies such as the conversion of fossil fuels to clean fuels in the nationwide Clean India Mission (CIM). However, such long-term or short-term reduction strategies seem to show insufficiency in the restoration of ambient air quality (Beig et al., 2013; Purohit et al., 2019; Banerjee et al., 2017).

Due to the pandemic of coronavirus disease 2019 (COVID-19), nationwide or partial lockdown measures have been implemented in many countries (Chintalapudi et al., 2020; Dantas et al., 2020; Ehrlich et al., 2020). The Indian government declared corresponding bans since the detection of the first confirmed case on 30 January 2020. Then, to counter the fast contagion of COVID-19, a 3-week nationwide lockdown was imposed in India on 24 March, which was extended until 30 June. The lockdown measures miti- 
gate the impact of COVID-19 on Indian health infrastructure and it also helped in curbing the rate of the spread of this infectious disease among people (Pai et al., 2020; Anderson et al., 2020). Because of the prohibition of industrial activities and mass transportation, anthropogenic emissions showed a tremendous reduction. As well as this, several studies showed that dramatic emission reductions had an enormous impact on the formation of air pollution and positively influenced air quality (Isaifan, 2020; Bao and Zhang, 2020; Gautam, 2020). Thus, the lockdown also provides a valuable opportunity to assess the changes in air pollutants with significantly reduced anthropogenic emissions in a short time.

Conspicuous reductions in concentrations of pollutants were also claimed in different regions (Otmani et al., 2020; Dantas et al., 2020; Nakada and Urban, 2020). Most Indian studies claimed the greatest reduction of particulate matter with an aerodynamic diameter of less than $2.5 \mu \mathrm{m}\left(\mathrm{PM}_{2.5}\right)$, up to $50 \%$ (Kumar et al., 2020; Mahato et al., 2020; Sharma et al., 2020). However, an increase in ozone $\left(\mathrm{O}_{3}\right)$ concentrations was observed (Collivignarelli et al., 2020; Sicard et al., 2020) and severe air pollution events still occurred after large emission reductions due to unfavorable meteorological conditions (Wang et al., 2020). Moreover, another analysis showed that the effects of lockdown during the COVID19 pandemic on $\mathrm{PM}_{2.5}$ and $\mathrm{O}_{3}$ pollution levels were smaller than the expected response to the enacted stay-at-home order (Bujin et al., 2020). Hence, the significance and impacts of lockdown measures are still not well understood.

Therefore, it is significant to understand the mechanisms involved in air pollution formation before and after dramatic emission changes comprehensively, in addition to the comparison of air pollution levels. Mahato et al. (2020) concluded that air quality in India from 24 March to 14 April improved sharply according to the change of the National Air Quality Index, especially for Delhi. Srivastava et al. (2020) reported the concentrations of primary air pollutants were drastically lowered as a result of emission reductions. Kumari and Toshniwal (2020) also stated that the concentration of key pollutants such as $\mathrm{PM}_{2.5}$ in both Delhi and Mumbai shows a decreasing trend. These studies pointed out that the air quality was improved during the lockdown period compared with the period before lockdown and depends on the duration of the lockdown (Kumar et al., 2020; Mor et al., 2021). As well as this, compared with the same period in previous years, Gautam (2020) claimed that aerosol concentration levels are at their lowest in the last 20 years during lockdown based on satellite data. Selvam et al. (2020) stated that the Air Quality Index (AQI) was improved by $58 \%$ in Gujarat state in western India during lockdown (24 March20 April 2020) compared to 2019. Kabiraj and Gavli (2020) concluded that the mean concentration of $\mathrm{PM}_{2.5}$ decreased by $42.25 \%$ from January to May in 2020 compared with 2019. Similarly, Das et al. (2020) also showed that great reductions of $\mathrm{PM}_{2.5}$ were found across cities in the IndoGangetic Plain (IGP) compared with 2018 and 2019. How- ever, the role of meteorological conditions and chemical reactions involving changes in air quality is not clear from these observation-based studies, which only showed the phenomenon of concentration reduction and switch of major primary pollutants mainly in urban cities. Further, the number of monitoring stations in the country is way below the guidelines given by the governing bodies and not uniformly distributed, which results in observation data limitations in India (Sahu et al., 2020).

In this study, the Community Multi-Scale Air Quality (CMAQ) model was used to investigate changes in air pollutants before the lockdown (from 21 February to 23 March 2020) and during the lockdown (from 24 March to 24 April 2020) periods throughout the Indian region. We explored the synergetic impacts from the meteorological conditions and anthropogenic emissions during the pre-lockdown and lockdown periods. As well as this, we directly quantified the change in air quality during the lockdown due to the reduced anthropogenic emissions by comparing the differences between Case 1 (without emission reductions) and Case 2 (with emission reductions). The model performance was evaluated by comparing the simulation results with the observation data, which is collected by the Central Pollution Control Board (CPCB). This study has important implications for developing control strategies to improve air quality in India.

\section{Methodology}

\subsection{Data collection}

We used observed hourly $\mathrm{PM}_{2.5}, \mathrm{O}_{3}$, carbon monoxide (CO), and nitrogen dioxide $\left(\mathrm{NO}_{2}\right)$ data from 21 February to 24 April 2020 from the CPCB online database (https://app. cpcbccr.com/ccr/\#/caaqm-dashboard-all/caaqm-landing, last access: 20 January 2021), which is widely applied in previous studies (Kumar, 2020; Sharma et al., 2020; Srivastava et al., 2020; Shehzad et al., 2020). The CPCB database provides data quality assurance (QA) or quality control (QC) programs by establishing strict procedures for sampling, analysis, and calibration (Gurjar et al., 2016). As well as this, the observed daily averages of $\mathrm{PM}_{2.5}$ and maximum daily $8 \mathrm{~h}$ average ozone (MDA8 $\mathrm{O}_{3}$ ) have been further calculated to analyze the change in air quality during the pre-lockdown (from 21 February to 23 March 2020) and lockdown (from 24 March to 24 April 2020). The satellite-observed $\mathrm{NO}_{2}$ and formaldehyde (HCHO) column number density datasets are from the Sentinel-5 Precursor TROPOspheric Monitoring Instrument (S-5P TROPOMI) (https://scihub.copernicus.eu, last access: 7 February 2021). As well as this, we effectively removed the pixels with a $\mathrm{QA}$ value less than 0.75 for $\mathrm{NO}_{2}$ tropospheric column density and 0.5 for $\mathrm{HCHO}$ from the datasets to exclude the interferences such as clouds and snow or ice (Apituley et al., 2018). 


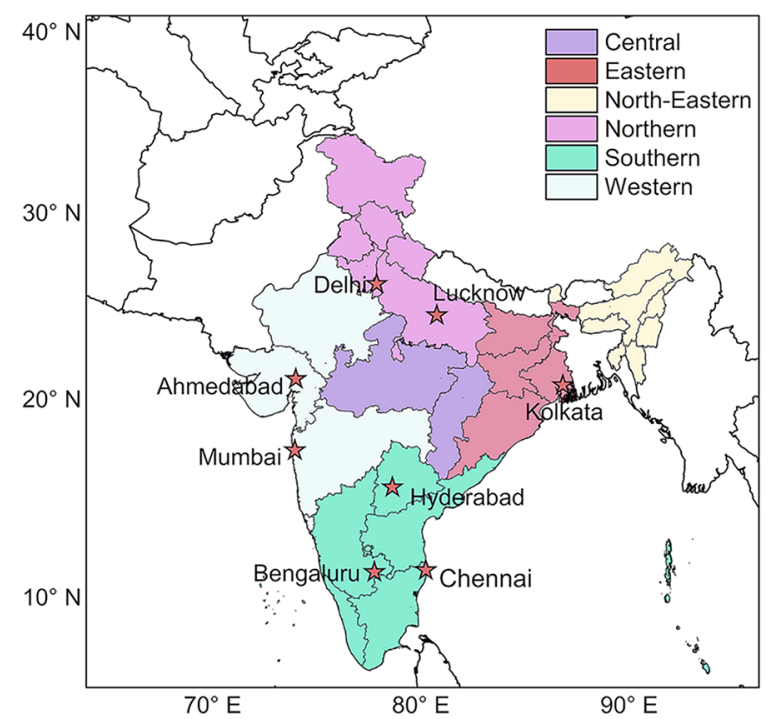

Figure 1. The simulation domain with the location of major Indian cities selected for analysis.

\subsection{Model description}

This study applied CMAQ (Byun and Schere, 2006) version 5.0.2 with an updated SAPRC-11 photochemical mechanism (Carter, 2011; Hu et al., 2016) and aerosol module (AERO6) (Binkowski and Roselle, 2003) to simulate air pollution across India with a horizontal resolution of $36 \mathrm{~km} \times 36 \mathrm{~km}(117 \times 117$ grid cells $)$. Figure 1 shows the simulation domain with positions of the main Indian cities. The simulation was conducted from 21 February to 23 March as a pre-lockdown and 24 March to 24 April as a lockdown period.

The Weather Research \& Forecasting model (WRF) version 3.6.1 was utilized to generate meteorology fields driven by the latest FNL (Final) Operational Global Analysis data. Anthropogenic emissions were from the monthly data from the Emissions Database for Global Atmospheric Research (EDGAR) version 4.3 (http://edgar.jrc.ec.europa.eu/ overview.php?v=431, last access: 20 September 2020). The monthly emissions from different source sectors were divided into six major groups, residential, industrial, agriculture, on-road, off-road, and energy, before being adjusted from the base year of 2010 to 2019 based on population and economic growths similar to Guo et al. (2017), and the adjustment factors are shown in Tables S1-S3 in the Supplement. Weekly and diurnal profiles were used to convert monthly emissions to hourly inputs, and the US EPA's SPECIATE 4.3 source profiles were used to speciate total particulate matter (PM) and volatile organic compounds (VOCs) to model species (Wang et al., 2014).

The biogenic emissions were derived from The Model of Emissions of Gases and Aerosols from Nature (MEGAN) version 2.1 (Guenther et al., 2012), and the emissions from
Table 1. The criteria on the "range of pollution index" for the purpose of categorization of industrial sectors.

\begin{tabular}{lr}
\hline Categories* & $\begin{array}{r}\text { Pollution index } \\
\text { score }\end{array}$ \\
\hline Very polluting (VP) & $\geq 60$ \\
Medium polluting (MP) & $41-59$ \\
Low polluting (LP) & $21-40$ \\
\hline
\end{tabular}

Note: * VP, MP, and LP industries are also defined as the red, orange, and green categories of industrial sectors respectively, based on the Indian Ministry of Environment, Forest and Climate Change website (https:

//pib.gov.in/newsite/printrelease.aspx?relid=137373).

biomass burning for 2018 were based on the Fire Inventory from the National Center for Atmospheric Research (FINN) (Wiedinmyer et al., 2011).

\subsection{Emission reduction during COVID-19}

Due to the COVID-19 lockdown, human activities were limited and related anthropogenic emissions were reduced. Different sources were used to obtain changes in anthropogenic emissions from different sectors in comparison to 2019.

For the sectors of on-road and off-road, the vehicle emission changes were based on the number of registered vehicles verified from the article (ET Bureau, 2020). The changes in energy demand were obtained from official data released by the Power System Operation Corporation (POSOCO) (Abdi, 2020). Residential and agricultural emissions remain unchanged due to a lack of sufficient information.

For the industrial sector, we classify the Indian industries into three different classes based on the degree of air pollution caused (https://www.indianmirror.com/ indian-industries/environment.html, last access: 7 February 2021) (Table S4) including very polluting (VP), medium polluting (MP), and low polluting (LP) industries. The pollution index (PI) of any industry is a number ranging from 0 to 100 and the increasing value of PI denotes the increasing degree of pollution load from the industry. As well as this, CPCB, State Pollution Control Boards (SPCBs), and the Ministry of Environment, Forest and Climate Change (MoEFCC) have finalized the criteria on the range of PI for the purpose of categorization of the industrial sector (https: //pib.gov.in/newsite/printrelease.aspx?relid=137373, last access: 7 February 2021) (Table 1).

Based on the above definition of the VP, MP, and LP industry, the emissions before lockdown can be expressed as follows:

$E_{1}=N_{\mathrm{VP}-\text { pre }} \times S_{\mathrm{VP}}+N_{\mathrm{MP} \text {-pre }} \times S_{\mathrm{MP}}+N_{\mathrm{LP}-\text { pre }} \times S_{\mathrm{LP}}$,

where $S_{\mathrm{VP}}, S_{\mathrm{MP}}$, and $S_{\mathrm{LP}}$ are $1,0.6$, and 0.4 as the assigned scores, and $N_{\mathrm{VP}-\text { pre }}, N_{\mathrm{MP} \text {-pre }}$, and $N_{\mathrm{LP}-p r e}$ are the number of each category industry before the lockdown. Similarly, the emissions during the lockdown are as follows: 
Table 2. Percentage reduction in anthropogenic emissions in India during the COVID-19 lockdown.

\begin{tabular}{lr}
\hline Sector & Percentage reduction \\
\hline Residential & 0 \\
Industrial & 82 \\
Agriculture & 0 \\
On-road & 85 \\
Off-road & 85 \\
Energy & 26 \\
\hline
\end{tabular}

$E_{2}=N_{\mathrm{VP}-\text { lock }} \times S_{\mathrm{VP}}+N_{\mathrm{MP}-\text { lock }} \times S_{\mathrm{MP}}+N_{\mathrm{LP} \text {-lock }} \times S_{\mathrm{LP}}$,

where $N_{\text {VP-lock }}, N_{\text {MP-lock}}$, and $N_{\text {LP-lock }}$ are the number of functioning industries during the lockdown. Therefore, the percentage reduction of industrial emissions can be calculated as follows:

$\%$ reduction $=\frac{E_{1}-E_{2}}{E_{1}} \times 100$.

In this study, two sensitivity simulations were conducted during the lockdown periods. Case 1 assumes business as usual with the same emissions as in 2019, while Case 2 adjusts anthropogenic emissions using factors obtained above for different sectors (Table 2). The differences between Case 2 and Case 1 can be assumed as the effects of COVID-19 lockdowns.

\section{Results and discussion}

\subsection{WRF-CMAQ model validation}

Meteorology plays an important role in emissions, transport, deposition, and formation of air pollutants (Zhang et al., 2015). Hence, the performance of WRF is validated to ensure accurate air pollution simulation against available observation from the National Climate Data Center (NCDC). There are more than 1300 stations within the simulation domain with hourly observations. The variables considered include temperature at $2 \mathrm{~m}$ above the surface (T2), wind speed (WS), wind direction (WD), and relative humidity (RH). Table S5 shows the statistics of mean observation and mean prediction of meteorological parameters, along with mean bias (MB), gross error (GE), and root mean squared error (RMSE), which are compared to benchmarks suggested by Emery et al. (2001). All the statistical indexes are listed in Table S6.

In general, the WRF model performance is similar to previous studies in India (Kota et al., 2018). For the prelockdown and lockdown period, predicted $\mathrm{T} 2$ was underestimated with $\mathrm{MB}$ values of -1.5 and $-1.2 \mathrm{~K}$, respectively. The GE values for WS were $1.7 \%$ (pre-lockdown) and $1.8 \%$ (lockdown), satisfying the suggested criteria of $2.0 \%$, and RMSE was slightly over the criteria. The MB values for WD were 3.2 and $2.6^{\circ}$ during the two periods, which are within the criteria of $\pm 10^{\circ}$. The GE and RMSE for WD were slightly out of the benchmarks. The under-predicted RH was also observed in this study, which was reported in other Asian studies (Hu et al., 2015). Those statistic values that did fall in the benchmark were mainly due to the resolution $(36 \mathrm{~km})$ applied in this study compared to the finer resolution (4-12 km) suggested in Emery et al. (2001) and Sahu et al. (2020).

Table $\mathrm{S} 7$ shows the model performance of MDA8 $\mathrm{O}_{3}$, $\mathrm{PM}_{2.5}, \mathrm{CO}$, and $\mathrm{NO}_{2}$ in five major cities in India including Delhi, Mumbai, Chennai, Hyderabad, and Bengaluru. For $\mathrm{PM}_{2.5}$, after excluding some abnormally high values of greater than $300 \mu \mathrm{g} \mathrm{m}^{-3}$, the averaged mean fractional bias (MFB) (-0.48) and mean fractional error (MFE) (0.61) values in all the five urban cites met the criteria limits of \pm 0.6 and 0.75 claimed by the EPA (2007). And the recommended criteria are commonly used for validating air quality model performance in the Indian region (Mohan and Gupta, 2018; Kota et al., 2018). For $\mathrm{O}_{3}$, a cut-off value of $40 \mathrm{ppb}$ is applied, which is based on EPA's recommendations (EPA, 2005). As well as this, the model was able to reproduce the variation trends of observed hourly $\mathrm{O}_{3}$ in all these major cities, although slightly over-estimations have occurred. And averaged MFB (-0.05) and MFE (0.25) values of $\mathrm{O}_{3}$ also satisfy the benchmarks of \pm 0.15 and 0.30 set by the EPA (2005) in most of these cities with Chennai and Hyderabad exceeding the limits slightly. The performance of $\mathrm{PM}_{2.5}, \mathrm{NO}_{2}, \mathrm{O}_{3}$, and $\mathrm{CO}$ in these urban areas was also similar to Kota et al. (2018), which could provide robust results for the following air quality study.

To further validate modeled $\mathrm{HCHO}$ and $\mathrm{NO}_{2}$, we compared our simulated results with satellite-observed data during pre-lockdown and lockdown periods (Fig. S1). The CMAQ predicted vertical column densities (VCDs) of tropospheric $\mathrm{NO}_{2}$ and $\mathrm{HCHO}$ were calculated using Eq. (4) (Eskes et al., 2020).

$\mathrm{VCD}=\sum_{i=1}^{n} C_{i} \times H_{i} \times \alpha$,

where $n$ equals 17 as the number of vertical layers in the model (with the highest layer height of $\sim 10 \mathrm{~km}$ ), $C_{i}$ means species concentration (ppm), $H_{i}$ represents each layer height (m), and $\alpha$ is the coefficient for converting units from ppm to molec. $\mathrm{cm}^{-2}$. The predicted regional distribution of tropospheric column $\mathrm{NO}_{2}$ and $\mathrm{HCHO}$ is similar to satellite observations. Overall, $\mathrm{HCHO}$ and $\mathrm{NO}_{2}$ are higher in eastern and northern India than in other regions. And their variation trends from CMAQ and TROPOMI are consistent so that $\mathrm{NO}_{2}$ decreases while $\mathrm{HCHO}$ increases during the lockdown. We also acknowledge that the uncertainty of the emission inventory and chemical mechanism in the modeling may affect the simulated results (Dominutti et al., 2020; Kitayama et al., 2019). 


\subsection{Changes in air quality from pre-lockdown to lockdown periods}

Figure 2 shows predicted and observed $\mathrm{PM}_{2.5}$ from 21 February to 24 April in Delhi, Mumbai, Chennai, Hyderabad, and Bengaluru. The model succeeds in estimating the observed peak and valley values with slight under-estimation in all these cities. Overall, sharp decreases are found in the observed $\mathrm{PM}_{2.5}$ in all these cities, and the averaged $\mathrm{PM}_{2.5}$ level drops from 43.18 to $27.62 \mu \mathrm{g} \mathrm{m}^{-3}$. The mean observed $\mathrm{PM}_{2.5}$ concentrations during lockdown are $42.47 \mu \mathrm{g} \mathrm{m}^{-3}$ (Delhi), $24.53 \mu \mathrm{g} \mathrm{m}^{-3}$ (Mumbai), $15.73 \mu \mathrm{g} \mathrm{m}^{-3}$ (Chennai), $31.29 \mathrm{\mu g} \mathrm{m}^{-3}$ (Hyderabad), and $24.08 \mu \mathrm{g} \mathrm{m}^{-3}$ (Bengaluru), which are reduced by $41 \%, 40 \%, 42 \%, 10 \%$, and $43 \%$ respectively compared with that of the pre-lockdown period. As well as this, the observed peak values of $\mathrm{PM}_{2.5}$ in each city also decrease appreciably (up to $57 \%$ ) during the lockdown period. On 24 March, the first day of lockdown, a significant drop in $\mathrm{PM}_{2.5}$ concentration due to the emission reduction of primary pollutants is observed (Fig. S2). However, most of the $\mathrm{PM}_{2.5}$ concentrations are still above the WHO annual guideline values of $10 \mu \mathrm{g} \mathrm{m}^{-3}$ (WHO, 2016) during the lockdown period, with peak values over $60 \mu \mathrm{g} \mathrm{m}^{-3}$ occasionally.

Figure 3 shows the temporal variation of MDA8 $\mathrm{O}_{3}$ in these five cities. The predicted MDA8 $\mathrm{O}_{3}$ is consistent in trend with observation values on most days, while simulated concentrations are overall higher, particularly in Hyderabad. The observed average MDA8 $\mathrm{O}_{3}$ during lockdown is higher than that before the lockdown in Delhi (2\%), Hyderabad $(12 \%)$, and Bengaluru (2\%). This is likely due to the fact that $\mathrm{O}_{3}$ formation in these cities is under VOC control (Sharma et al., 2020), and a nitrogen oxide $\left(\mathrm{NO}_{x}\right)$ reduction leads to an $\mathrm{O}_{3}$ increase by enhanced hydrogen oxide radical $\left(\mathrm{HO}_{x}\right)$ concentrations (Zhao et al., 2017). The increase in monthly average T2 from before the lockdown $(281.0 \mathrm{~K})$ to lockdown $\left(285.1 \mathrm{~K}\right.$ ) could also lead to an increase in $\mathrm{O}_{3}$ (Chen et al., 2019). In contrast, the observed average $\mathrm{MDA} 8 \mathrm{O}_{3}$ during lockdown is reduced compared with the pre-lockdown period in both Mumbai $(-35 \%)$ and Chennai $(-13 \%)$. This could be caused by a much larger reduction in emissions as Mumbai and Chennai with high urbanization and industrialization are the most affected areas. Specifically, more stringent lockdown measures may be implemented in Mumbai than we assumed, which accounted for more than a fifth of infections in India (Mukherjee, 2020).

Figure 4 shows the comparison of predicted air pollutants before and during the lockdown throughout India. Generally, decreases in key pollutants including particulate matter with an aerodynamic diameter of less than $10 \mu \mathrm{m}$ $\left(\mathrm{PM}_{10}\right)(-16 \%), \mathrm{PM}_{2.5}(-26 \%), \mathrm{MDA} 8 \mathrm{O}_{3}(-11 \%), \mathrm{NO}_{2}$ $(-50 \%)$, and sulfur dioxide $\left(\mathrm{SO}_{2}\right)(-14 \%)$ are calculated across India. Changes in these pollutants present distinct regional variations. In northern and western India, the lower levels of these pollutants are observed during the lockdown,

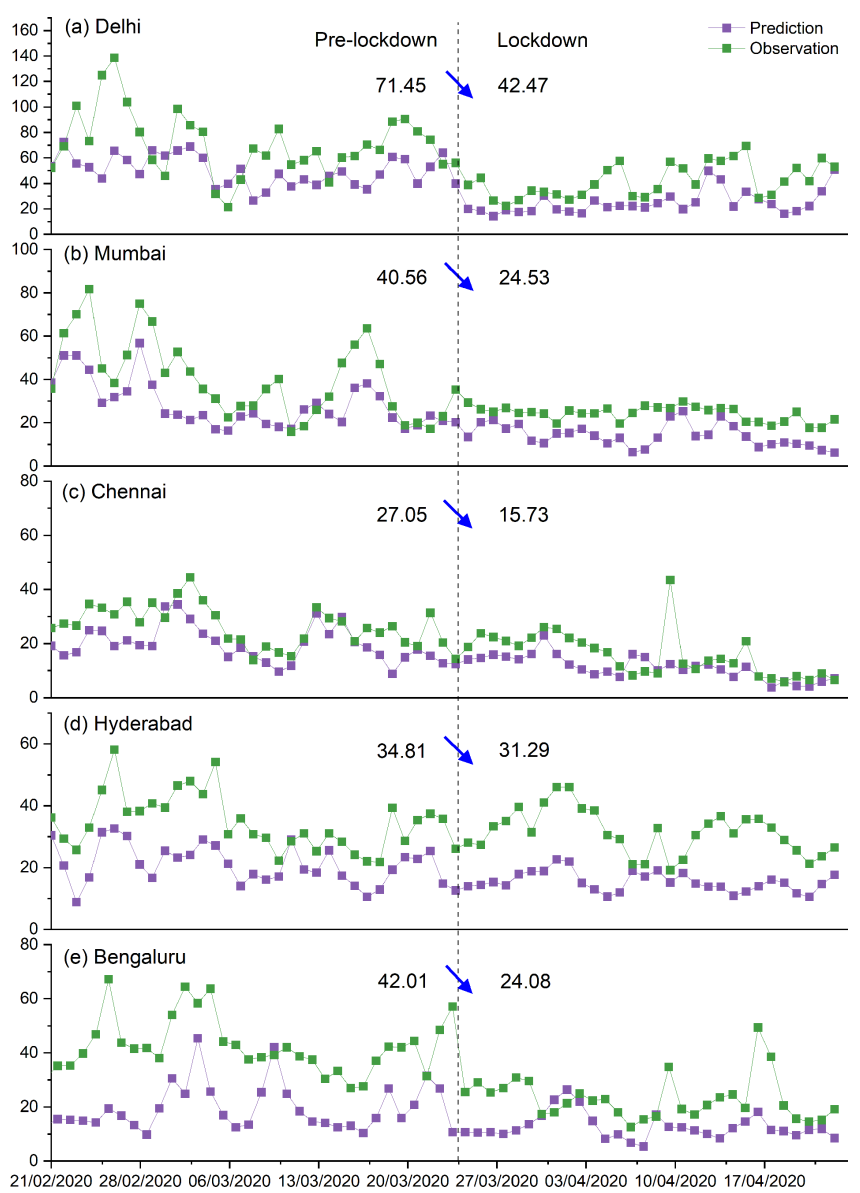

Figure 2. Comparison of predicted and observed $\mathrm{PM}_{2.5}$ from 21 February to 24 April 2020 in Delhi, Mumbai, Chennai, Hyderabad, and Bengaluru. The unit is $\mu \mathrm{g} \mathrm{m}^{-3}$.

with reductions of $\mathrm{PM}_{2.5}$ and $\mathrm{PM}_{10}$ of up to $79 \%$. In particular, the most significant decreases during the lockdown are found in the populated, industrialized, and polluted IGP region. The average $\mathrm{PM}_{2.5}$ even drops from approximately $35-70 \mu \mathrm{g} \mathrm{m}^{-3}$ (pre-lockdown) to $15-40 \mu \mathrm{g} \mathrm{m}^{-3}$ (lockdown) in these regions because local emissions are generally the largest contributor $(38 \%-78 \%)$ to $\mathrm{PM}_{2.5}$ in India (David et al., 2019). However, increases in these key pollutants are found mainly in the northeastern, eastern, and parts of southern India.

As well as this, changes in $\mathrm{PM}_{2.5}$ also show prominent differences in the rural and urban areas. In India, rural areas have different emission sources from urban areas and are less influenced by lockdown measures (Garaga et al., 2020). In megacities such as Delhi, the predicted concentrations of $\mathrm{PM}_{2.5}$ declined during the lockdown, which is consistent with previous results (Kumari and Toshniwal, 2020; Chauhan and Singh, 2020). For instance, a reduction of over $60 \%$ in $\mathrm{PM}_{2.5}$ is estimated in Delhi and Ahmedabad. However, increases in $\mathrm{PM}_{2.5}(\sim 20 \%)$ are observed in the remote northeastern part of India. Variations in near-surface mete- 


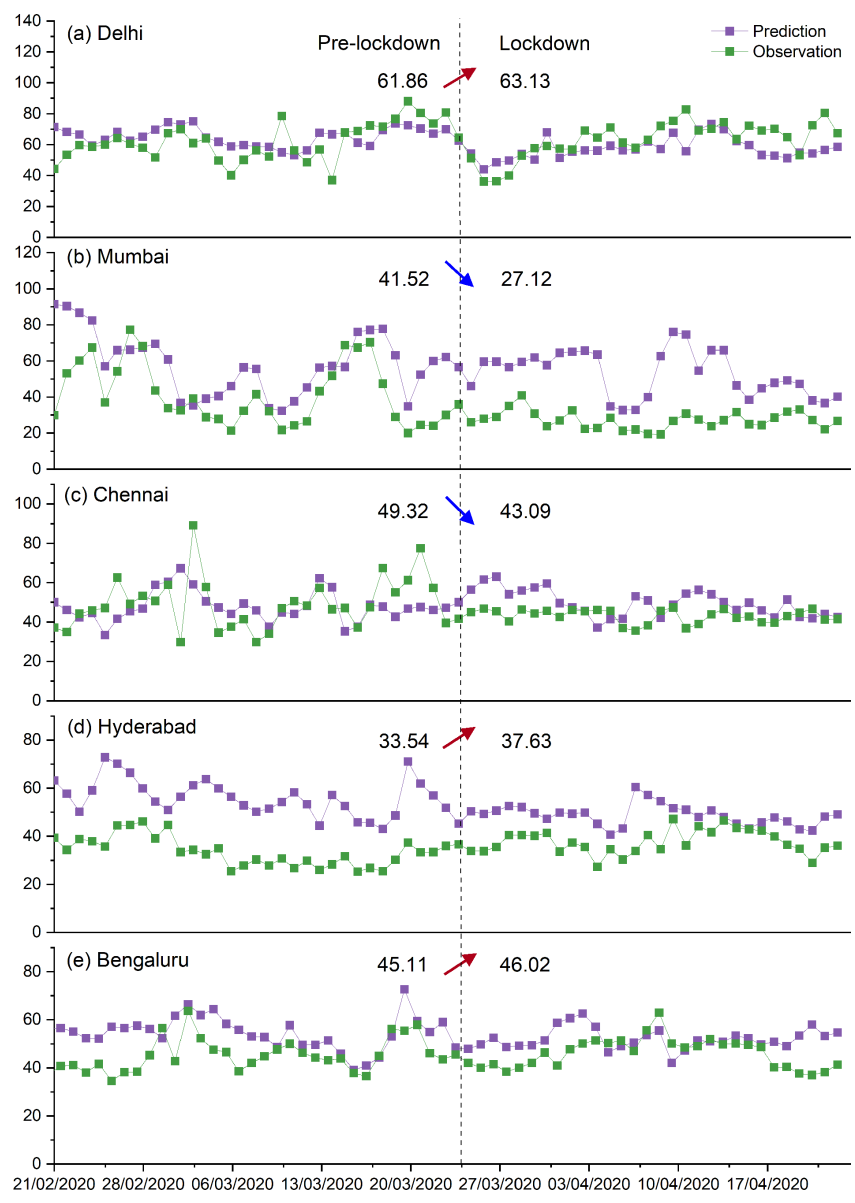

Figure 3. Comparison of predicted and observed $\mathrm{MDA} 8 \mathrm{O}_{3}$ from 21 February to 24 April 2020 in Delhi, Mumbai, Chennai, Hyderabad, and Bengaluru. The unit is ppb.

orological factors during lockdown also play an important role in $\mathrm{PM}_{2.5}$ changes. As is shown in Fig. S3, lower $\mathrm{PM}_{2.5}$ in urban areas during lockdown (Fig. 4) may be attributed to the decrease in RH and increase in planetary boundary layer (PBL) height, while the decrease in precipitation and WS allows $\mathrm{PM}_{2.5}$ to accumulate in some rural areas (Schnell et al., 2018; Le et al., 2020).

As gaseous precursors of major components to $\mathrm{PM}_{2.5}$ (Jain et al., 2020), concentrations of $\mathrm{NO}_{2}$ and $\mathrm{SO}_{2}$ also decrease significantly in most regions by up to $90 \%$ and $87 \%$, respectively. However, their levels increase in parts of eastern and southern India, thus leading to higher levels of $\mathrm{PM}_{2.5}$ and $\mathrm{PM}_{10}$ in the same regions. MDA8 $\mathrm{O}_{3}$ is also rising in eastern India by the highest increasing rate of $29 \%$, while a $30 \%$ reduction is observed in northern and western India. Although significant reductions are found in $\mathrm{O}_{3}$ precursor emissions throughout India during the lockdown, the $\mathrm{MDA} 8 \mathrm{O}_{3}$ has not shown a comparable decrease, which is affected by meteorological conditions such as an increase in temperature and decrease in RH (Fig. S3). Higher temperatures speed up photochemical processes that produce $\mathrm{O}_{3}$, while a higher $\mathrm{RH}$ re-
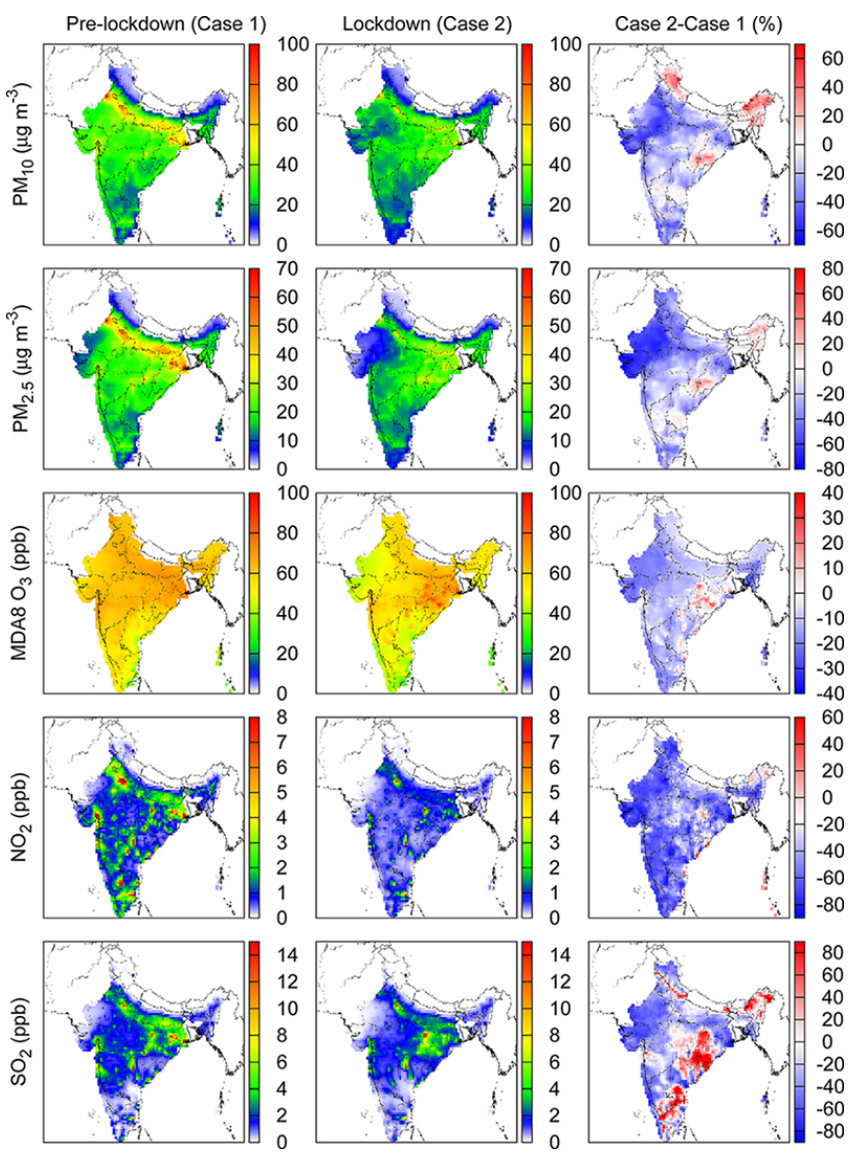

Figure 4. Predicted $\mathrm{PM}_{10}\left(\mu \mathrm{g} \mathrm{m}^{-3}\right), \mathrm{PM}_{2.5}\left(\mu \mathrm{g} \mathrm{m}^{-3}\right), \mathrm{MDA} 8 \mathrm{O}_{3}$ (ppb), $\mathrm{NO}_{2}(\mathrm{ppb})$, and $\mathrm{SO}_{2}$ (ppb) before lockdown, during the lockdown and the changes between them in India. "Case 2 - Case 1" indicates (Case 2-Case 1) / Case 1, reported as \%.

duces them (Chen et al., 2019; Zhao et al., 2017; Ali et al., 2012).

In summary, the decrease in $\mathrm{PM}_{2.5}, \mathrm{PM}_{10}, \mathrm{NO}_{2}$, and $\mathrm{SO}_{2}$ and the increase in MDA8 $\mathrm{O}_{3}$ during lockdown are consistent with previous results (Srivastava et al., 2020; Mahato et al., 2020). In the case of Delhi, compared with the previous studies, the $\mathrm{PM}_{2.5}$ reduction (34\%) is comparable with $35 \%$ reported by Chauhan and Singh (2020), with less than $53 \%$ stated by Mahato et al. (2020) and $49 \%$ calculated by Kumari and Toshniwal (2020) during the first phase of lockdown (from 24 March to 15 April 2020). These differences may be caused by the considered duration of the lockdown period. Our study concerns the later lockdown period (after 15 April 2020) when there is an increase in traffic flow and some relaxation of lockdown measures (Kumar, 2020). Moreover, the different characteristics of these air pollutants in rural and urban areas have not been investigated comprehensively in previous studies. Kumari and Toshniwal (2020) also concluded that concentrations of $\mathrm{PM}_{10}, \mathrm{PM}_{2.5}$, and $\mathrm{SO}_{2}$ tended to rise in Singrauli (rural area, located in central India) during the lockdown, contrary to the results of Delhi and 

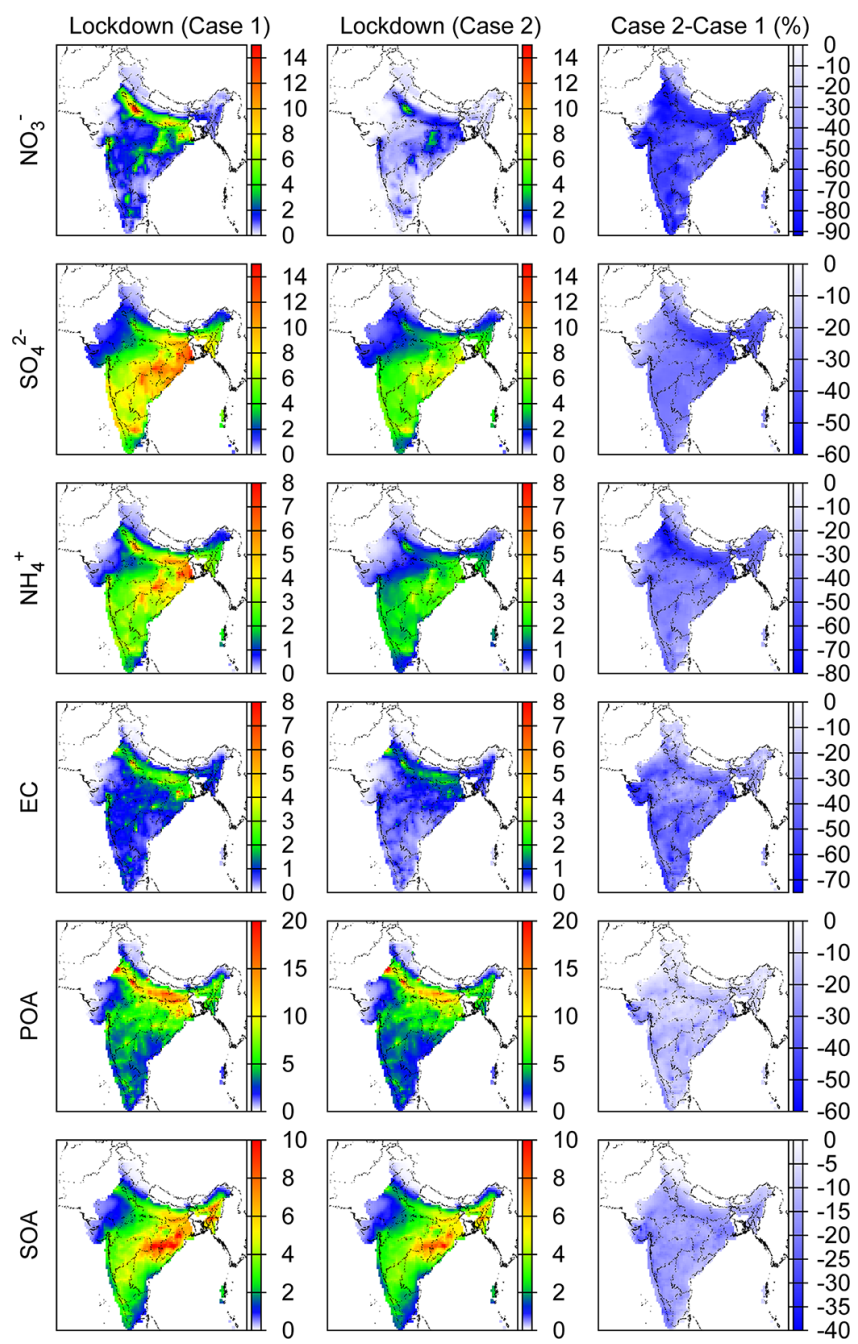

Figure 5. Predicted $\mathrm{PM}_{2.5}$ components and the changes caused by lockdown measures from 24 March to 24 April 2020 in India. The unit is $\mu \mathrm{g} \mathrm{m}^{-3}$. "Case 2-Case 1" indicates (Case 2-Case 1) / Case 1, reported as \%.

Mumbai. Therefore, our results have important implications for the study of air quality changes and their regional distribution across India and indicate more strident emission reduction policies should be implemented across India, especially in the later phases of lockdown and in rural areas.

\subsection{Effects of emission reductions on $\mathrm{PM}_{2.5}$ during the lockdown}

There are significant changes in $\mathrm{PM}_{2.5}$ between the lockdown and pre-lockdown periods. Moreover, we directly quantify the change in $\mathrm{PM}_{2.5}$ during the lockdown. Figure 5 shows the differences in major $\mathrm{PM}_{2.5}$ components during the lockdown period with (Case 2) and without (Case 1) control measures.

Major components of $\mathrm{PM}_{2.5}$ including nitrate $\left(\mathrm{NO}_{3}^{-}\right)$, sulfate $\left(\mathrm{SO}_{4}^{2-}\right)$, ammonium $\left(\mathrm{NH}_{4}^{+}\right)$, elemental carbon (EC), primary organic aerosols (POAs), and secondary organic aerosols (SOAs) decreased significantly in Case 2 compared to Case 1, indicating the positive effects of emission reduction. Primary components of $\mathrm{PM}_{2.5}$ (EC and POAs) are lowered by an average of $37 \%$ and $14 \%$, respectively. EC is usually emitted from combustion sources and a drastic decrease of up to $74 \%$ directly reflected the impact of emission reductions from industry and transportation. Secondary inorganic aerosols (SIAs) including $\mathrm{NO}_{3}^{-}, \mathrm{SO}_{4}^{2-}$, and $\mathrm{NH}_{4}^{+}$and SOAs accounted for most of the $\mathrm{PM}_{2.5}$ bulk mass (39\%) and showed greater decreases than primary components. Moreover, the spatial distribution of SIAs is similar to $\mathrm{PM}_{2.5}$ in that the reduction is more significant in the north of India where the decrease in $\mathrm{NO}_{3}^{-}, \mathrm{SO}_{4}^{2-}$, and $\mathrm{NH}_{4}^{+}$are up to $92 \%$, $57 \%$, and $79 \%$ respectively. The largest reduction of $\mathrm{NO}_{3}^{-}$, averaging $62 \%$, resulted from transportation reduction, and the $\mathrm{SO}_{4}^{2-}$ reduction (averaging $31 \%$ ) is likely due to the falling industry emissions (Gawhane et al., 2017; Wang et al., 2020). On average, $\mathrm{NH}_{4}^{+}$and SOAs are decreased by $41 \%$ and $14 \%$, respectively. The significant decrease in $\mathrm{NH}_{4}^{+}$cannot be attributed to the absence of reduced agricultural emissions in the simulation but may be due to the relatively reduced $\left(\mathrm{NH}_{4}\right)_{2} \mathrm{SO}_{4}$ and $\mathrm{NH}_{4} \mathrm{NO}_{3}$ in the CMAQ chemistrytransport model (Fountoukis and Nenes, 2007). By contrast, compared with VOCs, an important precursor of SOAs, the smaller reduction of SOAs may be related to the weakening of the atmospheric oxidizing capacity (AOC), which plays an important role in the formation of SOAs (Feng et al., 2019). As well as this, the reduction of $\mathrm{NO}_{x}$ may lead to an increase in SOAs offsetting some of the influence by the reduction in VOC emissions (Kroll et al., 2020).

Figure 6 shows the predicted response of changes in concentration of primary $\mathrm{PM}_{2.5}$ (PPM) and secondary components to the reduced emissions of related precursors in Delhi, Mumbai, Kolkata, Bengaluru, Hyderabad, Chennai, Ahmedabad, and Lucknow. Generally, all species decreased with the reduced emissions and the great sensitivity of $\mathrm{PM}_{2.5}$ component concentrations to emissions showed the important role of meteorology and the effectiveness of stringent measures to reduce emissions.

On average, $\mathrm{NO}_{3}^{-}$shares the largest reduction of $77 \%$ mainly driven by the decrease in its gaseous precursor $\mathrm{NO}_{x}$ $(71 \%)$. At least a $27 \%$ decrease in $\mathrm{SO}_{4}^{2-}$ is found in each city caused by the largest reduction of $\mathrm{SO}_{2}$ (averaged $59 \%$ ). An average reduction of over $70 \%$ in $\mathrm{NO}_{x}$ and $\mathrm{NO}_{3}^{-}$may still be related to the reduction of vehicles. And SOAs dropped by an average of $18 \%$ because of the lack of precursors due to the emission reduction of VOCs $(29 \%)$. Due to the reduction of emitting precursors, the concentration reduction of $\mathrm{PM}_{2.5}$ secondary components is less than that of primary components. The ratios of PPM reduction in emission (averaged 39\%) are larger than the reduction in concentration (averaged $43 \%$ ) in five selected cities. In particular, a $7 \%$ reduction in emission of PPM caused a $43 \%$ decline in its concentration in Hyderabad. Emissions of EC and organic 


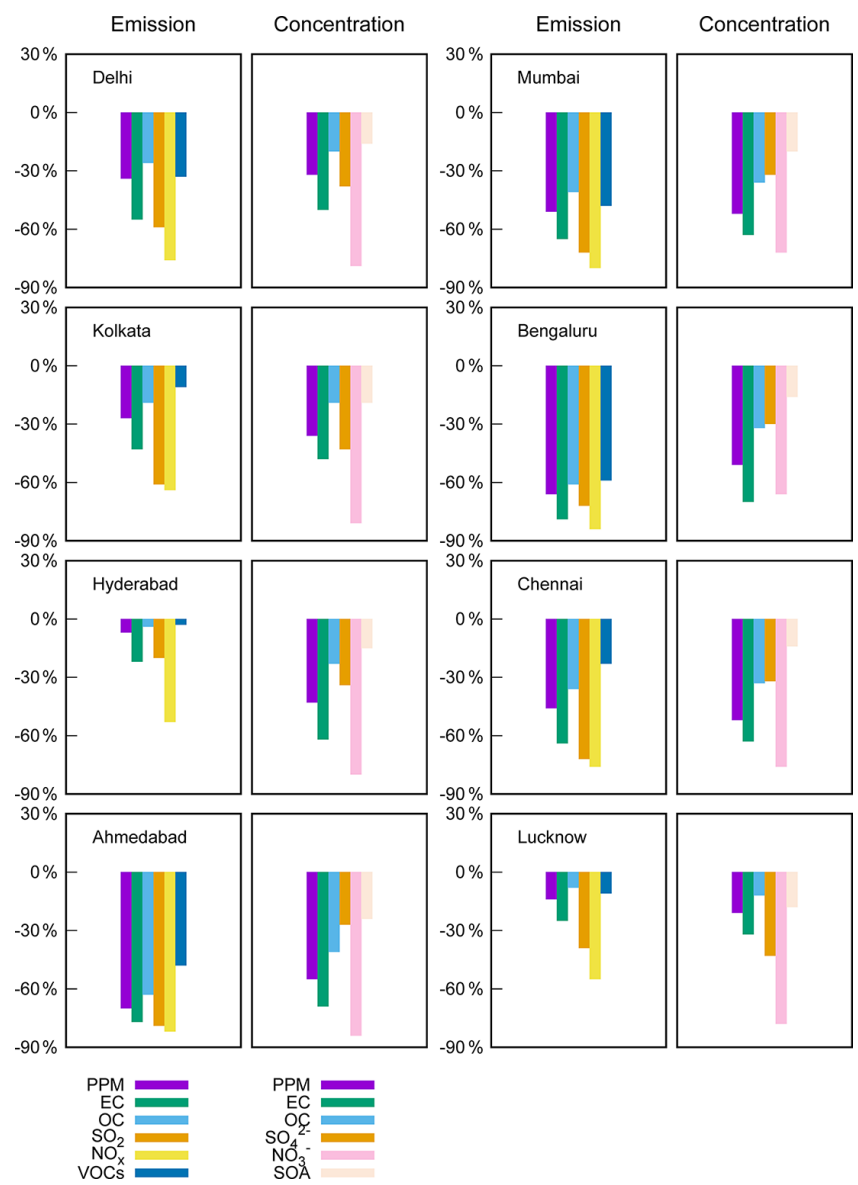

Figure 6. Predicted relative changes in concentrations of primary and secondary components, and emissions of their precursors in eight cities of India in Case 2 to Case 1.

carbon (OC) have also been reduced by a certain proportion resulting in a similar or greater reduction in concentrations.

The response of concentration to emissions in all cities presented a nonlinear change that has been confirmed previously by Zhao et al. (2017), which is related to various meteorological conditions (Wang et al., 2020). For example, in Lucknow, PPM, EC, $\mathrm{OC}, \mathrm{SO}_{2}, \mathrm{NO}_{x}$, and VOCs decreased by $14 \%, 25 \%, 8 \%, 39 \%, 55 \%$, and $11 \%$ respectively, while the concentration of PPM, EC, OC, $\mathrm{SO}_{4}^{2-}, \mathrm{NO}_{3}^{-}$, and SOAs dropped by $21 \%, 32 \%, 12 \%, 43 \%, 78 \%$, and $18 \%$. As well as this, the concentration response to emission reduction is likely to be more prominent in highly polluted and industrialized areas. The highest reductions in PPM and these secondary components of $\mathrm{PM}_{2.5}$ happened in Ahmedabad (an industrial city located in western India) with high vehicular populations. Bengaluru, a major southern Indian city, is considered as one of the cleaner Indian major cities because of its low $\mathrm{PM}_{2.5}$ concentrations with no heavy industries (Guttikunda et al., 2019). Consequently, the reduction in $\mathrm{PM}_{2.5}$ and its major components (especially for secondary compo-
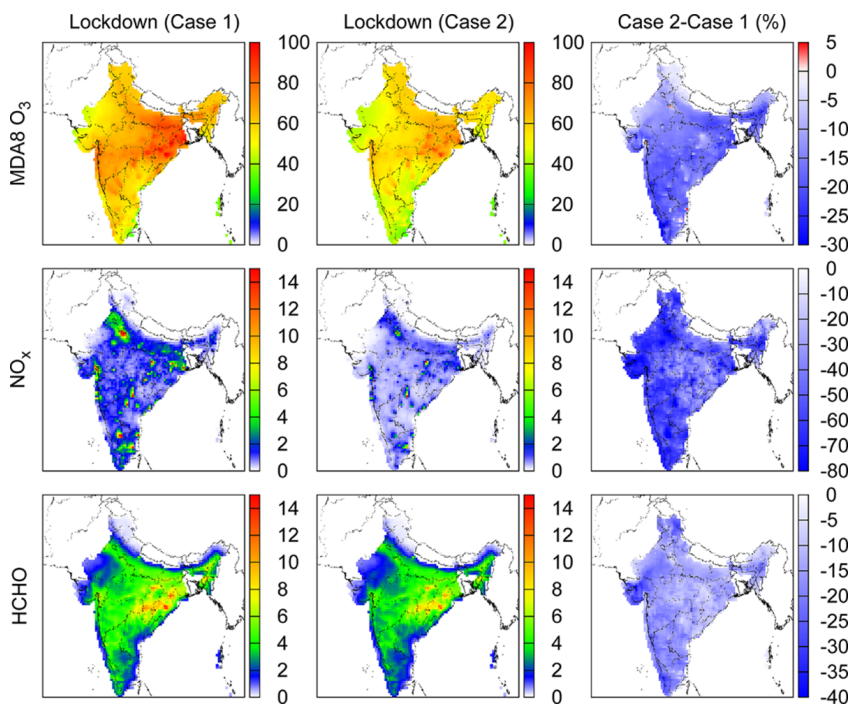

Figure 7. Predicted $\mathrm{O}_{3}, \mathrm{NO}_{x}, \mathrm{HCHO}$, and the changes caused by nationwide lockdown measures from 24 March to 24 April 2020 in India. The unit is ppb. "Case 2-Case 1" indicates (Case 2-Case 1) / Case 1, reported as \%.

nents) in Bengaluru is not as significant as in Ahmedabad although a similar reduction in emissions is observed.

\subsection{Effects of emission reductions on $\mathrm{O}_{3}$ during the lockdown}

We investigated the changes of MDA8 $\mathrm{O}_{3}$ and its major precursors $\mathrm{NO}_{x}$ and $\mathrm{HCHO}$ during the lockdown period. $\mathrm{HCHO}$ is one of the major contributors to total VOC reactivity (Zhang et al., 2012; Steiner et al., 2008). It also has a strong correlation with VOC ( $R^{2}$ up to 0.93 ) (Fig. S4) and performs well when validated by comparing with satelliteobserved data. As a result, $\mathrm{HCHO}$ is used as a good proxy in the model for the total VOCs, consistent with previous studies such as Palmer et al. (2003). Figure 7 shows that MDA8 $\mathrm{O}_{3}, \mathrm{NO}_{x}$, and $\mathrm{HCHO}$ decreased all over India. The average reduction rates of MDA8 $\mathrm{O}_{3}, \mathrm{NO}_{x}$, and $\mathrm{HCHO}$ are approximately $15 \%, 50 \%$, and $15 \%$, respectively. For both Case 1 and Case 2, the higher levels of MDA8 $\mathrm{O}_{3}$ are in eastern India (over $60 \mathrm{ppb}$, Case 1) in which the higher $\mathrm{NO}_{x}$ is also observed (over $12 \mathrm{ppb}$, Case 1) during the lockdown. Compared to $\mathrm{PM}_{2.5}$, no significant north-south differences are found in the change of $\mathrm{O}_{3}$. The $\mathrm{NO}_{x}$ concentration has the greatest reduction that is mostly driven by the large cutting of energy emission by $26 \%$, which is consistent with the decline of India's electricity consumption $(9.2 \%)$ (Reuters, 2020).

Figure $\mathrm{S} 5$ shows the $\mathrm{O}_{3}$ production sensitivity $\left(\mathrm{O}_{3} / \mathrm{NO}_{y}\right)$ in India during the lockdown, which is considered as an indicator of $\mathrm{O}_{3}$ sensitivity to $\mathrm{NO}_{x}$ and VOCs (Sillman, 1995; Sillman and $\mathrm{He}, 2002)$. As well as this, $\mathrm{O}_{3} / \mathrm{NO}_{y}<6$ indicates that $\mathrm{O}_{3}$ formation is VOC-limited, $\mathrm{O}_{3} / \mathrm{NO}_{y}>8$ indicates $\mathrm{NO}_{x}$-limited, and intermediate values are transitional. 
In India, $\mathrm{NO}_{x}$-limited regimes are found in vast areas from both Case 1 and Case 2, which was also reported in previous studies (Mahajan et al., 2015). As a result, the large reduction of $\mathrm{NO}_{x}$ leads to decreased MDA8 $\mathrm{O}_{3}$ in most Indian regions. Compared to Case 1, the VOC-limited area expands mainly in the northwest and south of India from Case 2 during the lockdown. Simultaneously, the rise of $\mathrm{MDA}_{8} \mathrm{O}_{3}$ (averaged $5 \%$ and up to $21 \%$ ) is found sporadically in these VOC-limited areas in which more significant decreases in $\mathrm{NO}_{x}$ (compared with VOCs) reduce the $\mathrm{O}_{3}$ consumption $\left(\mathrm{NO}+\mathrm{O}_{3}=\mathrm{NO}_{2}+\mathrm{O}_{2}\right)$ and enhance $\mathrm{HO}_{x}$ concentrations, resulting in an increase in $\mathrm{O}_{3}$ levels. It may also indicate that the increase in $\mathrm{O}_{3}$ is amplified regionally by the expansion of the VOC-limited regimes due to the lockdown.

Figure 8 compares the concentrations of MDA8 $\mathrm{O}_{3}$, $\mathrm{HCHO}$, and $\mathrm{NO}_{x}$ with emissions of VOCs, HCHO, and $\mathrm{NO}_{x}$ in eight major cities of India, Delhi, Mumbai, Kolkata, Bengaluru, Hyderabad, Chennai, Ahmedabad, and Lucknow. Generally, the decline in $\mathrm{O}_{3}$ concentration in Delhi (14\%), Mumbai (23\%), Kolkata (24\%), Bengaluru (20\%), Hyderabad (17\%), Chennai (20\%), Ahmedabad (21\%), and Lucknow $(15 \%)$ showed that effectiveness of emission reductions that play an important role in the control of $\mathrm{O}_{3}$ pollution, even in these VOC-limited areas.

The changes in emissions and concentrations of MDA8 $\mathrm{O}_{3}, \mathrm{HCHO}$, and $\mathrm{NO}_{x}$ showed a non-linear response. In Delhi, a $76 \%$ reduction in $\mathrm{NO}_{x}$ emissions resulted in a $77 \%$ reduction in its concentration, while a $29 \%$ reduction in $\mathrm{HCHO}$ resulted in only an $11 \%$ reduction. In a megacity like Delhi, about 7 million vehicles and many fossil-fuel-based plants lead to high $\mathrm{NO}_{x}$ emissions, and local restricted transportation and industrial activities during lockdown could lead to a significant reduction of primary $\mathrm{NO}_{x}$ emissions (Sharma et al., 2016). The concentration of $\mathrm{NO}_{x}$ is appreciably highly sensitive to a primary $\mathrm{NO}_{x}$ emission reduction. However, the VOCs emission reduction resulting from the lockdown is relatively less than $\mathrm{NO}_{x}$ in each city. And most of the reduction of HCHO concentration is less than that of emission reduction, which is different from $\mathrm{NO}_{x}$, which indicated that the change of $\mathrm{HCHO}$ concentrations is not dominated by primary $\mathrm{HCHO}$ emission reduction.

\section{Conclusion}

Compared with before the lockdown, observed $\mathrm{PM}_{2.5}$ during the lockdown in Delhi, Mumbai, Chennai, Hyderabad, and Bengaluru shows an overall decrease. In contrast, $\mathrm{MDA} 8 \mathrm{O}_{3}$ increases in three of these cities. The comparison of predicted air pollutants across India before and during the lockdown shows distinct regional characteristics. The most significant reductions of $\mathrm{PM}_{2.5}$ and $\mathrm{PM}_{10}$ (up to $79 \%$ ) are observed in most of northern and western India including all these megacities. However, increases in MDA8 $\mathrm{O}_{3}$ (up to 29\%) and other key pollutants are reported in northeastern, east-

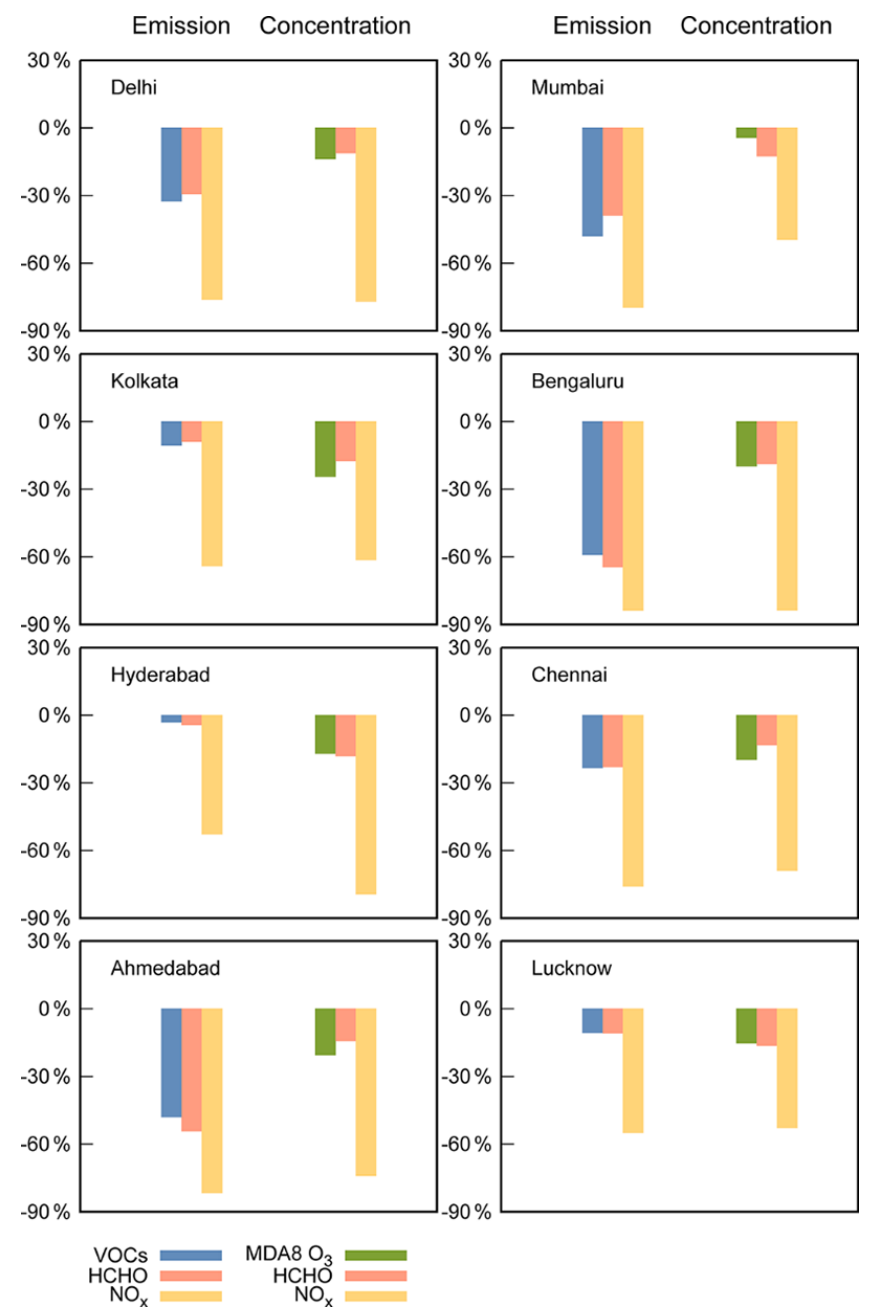

Figure 8. Predicted relative changes in concentrations of $\mathrm{O}_{3}$, $\mathrm{HCHO}$, and $\mathrm{NO}_{x}$ and emissions of VOCs, $\mathrm{HCHO}$, and $\mathrm{NO}_{x}$ in eight major cities of India in Case 2 to Case 1.

ern, and parts of southern India covering most of the rural areas. As well as this, it can be concluded that the synergetic impact from the meteorological conditions and anthropogenic emissions plays an important role in those increases from pre-lockdown to lockdown periods.

The drastic decline in $\mathrm{PM}_{2.5}$ and its major components during the lockdown period in Case 2 compared with Case 1 shows the positive impacts of emission control measures, especially for SIAs. During the lockdown, the decrease in MDA8 $\mathrm{O}_{3}$ (averaged $15 \%$ ) occurs in most regions in India, which is attributed to the lower emissions of $\mathrm{NO}_{x}(48 \%)$ and VOCs $(6 \%)$ that are precursors of $\mathrm{O}_{3}$. Our results demonstrate that the strident emission controls due to the lockdown have mitigated air pollution in India. However, more stringent mitigation measures are needed to achieve effective control of air pollution from secondary air pollutants and their components, particularly in rural areas. We also find the scattered increases in MDA8 $\mathrm{O}_{3}$ (up to $21 \%$ ) in some urban lo- 
cations in the VOC-limited areas due to the emission reduction. This indicates that a more localized control policy with the consideration of the $\mathrm{O}_{3}$ sensitivity regime should be implemented in India to improve the air quality, especially for secondary pollutants such as $\mathrm{O}_{3}$.

Data availability. The datasets used in the study can be accessed from websites listed in the references or by contacting the corresponding authors (peng.ce.wang@polyu.edu.hk and zhanghl@fudan.edu.cn).

Supplement. The supplement related to this article is available online at: https://doi.org/10.5194/acp-21-4025-2021-supplement.

Author contributions. MZ conducted the modeling and led the writing of the paper. AK carried out the data collection and initial analysis. SZ, JS, and JM assisted with the data analysis. MX and SHK assisted with the interpretation of the results and the writing of the paper. HZ and PW designed the study, discussed the results, and edited the paper.

Competing interests. The authors declare that they have no conflict of interest.

Acknowledgements. We acknowledge the publicly available WRF and CMAQ models that make this study possible.

Financial support. This research has been supported by the Institute of Eco-Chongming (grant no. ECNU-IEC-202001).

Review statement. This paper was edited by Frank Dentener and reviewed by three anonymous referees.

\section{References}

Abdi, B.: The Economic Times, Coronavirus impact: Within ten days, 26 per cent fall in India's energy consumption, available at: https://energy.economictimes.indiatimes.com/news/power/, last access: 27 August 2020.

Ali, K., Inamdar, S. R., Beig, G., Ghude, S., and Peshin, S.: Surface ozone scenario at Pune and Delhi during the decade of 1990s, J. Earth Syst. Sci., 121, 373-383, https://doi.org/10.1007/s12040012-0170-1, 2012.

Anderson, R. M., Heesterbeek, H., Klinkenberg, D., and Hollingsworth, T. D.: How will country-based mitigation measures influence the course of the COVID-19 epidemic?, Lancet, 395, 931-934, https://doi.org/10.1016/s0140-6736(20)30567-5, 2020.

Apituley, A., Pedergnana, M., Sneep, M., Pepijn Veefkind, J., Loyola, D., Landgraf, J., and Borsdorff, T.: Sentinel-
5 Precursor/TROPOMI Level 2 Product User Manual Carbon Monoxide, SRON-S5P-LEV2-MA-002, avaliable at: http://www.tropomi.eu/sites/default/files/files/ Sentinel-5P-Level-2-Product-User-Manual-CarbonMonoxide_ v1.00.02_20180613.pdf (last access: 7 February 2021), 2018.

Balakrishnan, K., Dey, S., Gupta, T., Dhaliwal, R. S., Brauer, M., Cohen, A. J., Stanaway, J. D., Beig, G., Joshi, T. K., Aggarwal, A. N., Sabde, Y., Sadhu, H., Frostad, J., Causey, K., Godwin, W., Shukla, D. K., Kumar, G. A., Varghese, C. M., Muraleedharan, P., Agrawal, A., Anjana, R. M., Bhansali, A., Bhardwaj, D., Burkart, K., Cercy, K., Chakma, J. K., Chowdhury, S., Christopher, D. J., Dutta, E., Furtado, M., Ghosh, S., Ghoshal, A. G., Glenn, S. D., Guleria, R., Gupta, R., Jeemon, P., Kant, R., Kant, S., Kaur, T., Koul, P. A., Krish, V., Krishna, B., Larson, S. L., Madhipatla, K., Mahesh, P. A., Mohan, V., Mukhopadhyay, S., Mutreja, P., Naik, N., Nair, S., Nguyen, G., Odell, C. M., Pandian, J. D., Prabhakaran, D., Prabhakaran, P., Roy, A., Salvi, S., Sambandam, S., Saraf, D., Sharma, M., Shrivastava, A., Singh, V., Tandon, N., Thomas, N. J., Torre, A., Xavier, D., Yadav, G., Singh, S., Shekhar, C., Vos, T., Dandona, R., Reddy, K. S., Lim, S. S., Murray, C. J. L., Venkatesh, S., and Dandona, L.: The impact of air pollution on deaths, disease burden, and life expectancy across the states of India: the Global Burden of Disease Study 2017, Lancet Planet. Health, 3, e26-e39, https://doi.org/10.1016/S2542-5196(18)30261-4, 2019.

Banerjee, T., Kumar, M., Mall, R. K., and Singh, R. S.: Airing 'clean air' in Clean India Mission, Environ. Sci. Pollut. Res., 24, 63996413, https://doi.org/10.1007/s11356-016-8264-y, 2017.

Bao, R. and Zhang, A.: Does lockdown reduce air pollution? Evidence from 44 cities in northern China, Sci. Total Environ., 731, 139052, https://doi.org/10.1016/j.scitotenv.2020.139052, 2020.

Beig, G., Chate, D. M., Ghude, S. D., Mahajan, A. S., Srinivas, R., Ali, K., Sahu, S. K., Parkhi, N., Surendran, D., and Trimbake, H. R.: Quantifying the effect of air quality control measures during the 2010 Commonwealth Games at Delhi, India, Atmos. Environ., 80, 455-463, https://doi.org/10.1016/j.atmosenv.2013.08.012, 2013.

Binkowski, F. S. and Roselle, S. J.: Models-3 Community Multiscale Air Quality (CMAQ) model aerosol component 1. Model description, J. Geophys. Res.-Atmos., 108, 4183, https://doi.org/10.1029/2001JD001409, 2003.

Bujin, B., Joshua, S. A., Dylan, B. M., Allen, R., Kelley, C. W., and Julian, D. M.: $\mathrm{PM}_{2.5}$ and Ozone Air Pollution Levels Have Not Dropped Consistently Across the US Following Societal Covid Response, ChemRxiv [preprint], https://doi.org/10.26434/chemrxiv.12275603.v3, 2020.

Byun, D. and Schere, K. L.: Review of the governing equations, computational algorithms, and other components of the models3 Community Multiscale Air Quality (CMAQ) modeling system, Appl. Mech. Rev., 59, 51-77, https://doi.org/10.1115/1.2128636, 2006.

Carter, W. P. L.: SAPRC Atmospheric Chemical Mechanisms and VOC Reactivity Scales, available at: https://intra.engr.ucr.edu/ $\sim$ carter/SAPRC/ (last access: 26 August 2020), 2011.

Chauhan, A. and Singh, R. P.: Decline in $\mathrm{PM}_{2.5}$ concentrations over major cities around the world associated with COVID-19, Environ. Res., 187, 109634, https://doi.org/10.1016/j.envres.2020.109634, 2020. 
Chen, Z., Zhuang, Y., Xie, X., Chen, D., Cheng, N., Yang, L., and Li, R.: Understanding long-term variations of meteorological influences on ground ozone concentrations in Beijing During 2006-2016, Environ. Pollut., 245, 29-37, https://doi.org/10.1016/j.envpol.2018.10.117, 2019.

Chintalapudi, N., Battineni, G., and Amenta, F.: COVID19 virus outbreak forecasting of registered and recovered cases after sixty day lockdown in Italy: A data driven model approach, J. Microbiol. Immunol., 53, 396-403, https://doi.org/10.1016/j.jmii.2020.04.004, 2020.

Collivignarelli, M. C., Abba, A., Bertanza, G., Pedrazzani, R., Ricciardi, P., and Carnevale Miino, M.: Lockdown for CoViD-2019 in Milan: What are the effects on air quality?, Sci. Total Environ., 732, 139280, https://doi.org/10.1016/j.scitotenv.2020.139280, 2020.

Dantas, G., Siciliano, B., Franca, B. B., da Silva, C. M., and Arbilla, G.: The impact of COVID-19 partial lockdown on the air quality of the city of Rio de Janeiro, Brazil, Sci. Total Environ., 729, 139085, https://doi.org/10.1016/j.scitotenv.2020.139085, 2020.

Das, M., Das, A., Sarkar, R., Saha, S., and Mandal, A.: Examining the impact of lockdown (due to COVID-19) on ambient aerosols $\left(\mathrm{PM}_{2.5}\right)$ : A study on Indo-Gangetic Plain (IGP) Cities, India, Stoch. Env. Res. Risk A., 16, 1-17, https://doi.org/10.1007/s00477-020-01905-x, 2020.

David, L. M., Ravishankara, A. R., Kodros, J. K., Pierce, J. R., Venkataraman, C., and Sadavarte, P.: Premature Mortality Due to $\mathrm{PM}_{2.5}$ Over India: Effect of Atmospheric Transport and Anthropogenic Emissions, Geohealth, 3, 2-10, https://doi.org/10.1029/2018GH000169, 2019.

Dominutti, P., Nogueira, T., Fornaro, A., and Borbon, A.: One decade of VOCs measurements in São Paulo megacity: Composition, variability, and emission evaluation in a biofuel usage context, Sci. Total Environ., 738, 139790, https://doi.org/10.1016/j.scitotenv.2020.139790, 2020.

Ehrlich, H., McKenney, M., and Elkbuli, A.: Protecting our healthcare workers during the COVID-19 pandemic, Am. J. Emerg. Med., 38, 1527-1528, https://doi.org/10.1016/j.ajem.2020.04.024, 2020.

Emery, C., Tai, E., and Yarwood, G.: Enhanced Meteorological Modeling and Performance Evaluation for Two texas Episodes, Report to the Texas Natural Resources Conservation Commission, Prepared by ENVIRON, International Corp., Novato, CA, available at: http://www.tceq.state.tx.us/ assets/public/implementation/air/am/contracts/reports/mm/

EnhancedMetModelingAndPerformanceEvaluation.pdf (last access: 27 August 2020), 2001.

EPA: Guidance on the Use of Models and Other Analyses in Attainment Demonstrations for the 8-hour Ozone, NAAQSRep, available at: https://nepis.epa.gov/Exe/ZyPDF.cgi/P1006FPU.PDF? Dockey=P1006FPU.PDF, (last access: 27 August 2020), 2005.

EPA: Guidance on the use of models and other analyses for demonstrating attainment of air quality goals for ozone, $\mathrm{PM}_{2.5}$, and regional haze, US Environmental Protection Agency, Office of Air Quality Planning and Standards, available at: https://nepis.epa.gov/Exe/ZyPDF.cgi/P1009OL1.PDF? Dockey=P1009OL1.PDF (last access: 27 August 2020), 2007.

Eskes, K.-U. E., Lambert, J.-C., Loyola, D., Veefkind, J. P., Dehn, A., and Zehner, C.: S5P Mission Performance Centre Nitrogen Dioxide [L2_NO2_] Readme, avail- able at: https://sentinel.esa.int/documents/247904/3541451/ Sentinel-5P-Nitrogen-Dioxide-Level-2-Product-Readme-File (last access: 7 February 2021), 2020.

ET Bureau: The Economic Times, Move only essential items: Transport body to members, available at: https://economictimes. indiatimes.com/industry/transportation/shipping-/-transport/ move-only-essential-items-transport-body-to-members/ articleshow/75016374.cms?from=mdr, last access: $27 \mathrm{Au}-$ gust 2020.

Feng, T., Zhao, S., Bei, N., Wu, J., Liu, S., Li, X., Liu, L., Qian, Y., Yang, Q., Wang, Y., Zhou, W., Cao, J., and Li, G.: Secondary organic aerosol enhanced by increasing atmospheric oxidizing capacity in Beijing-Tianjin-Hebei (BTH), China, Atmos. Chem. Phys., 19, 7429-7443, https://doi.org/10.5194/acp19-7429-2019, 2019.

Fountoukis, C. and Nenes, A.: ISORROPIA II: a computationally efficient thermodynamic equilibrium model for $\mathrm{K}^{+}$ $\mathrm{Ca}^{2+}-\mathrm{Mg}^{2+}-\mathrm{NH}_{4}^{+}-\mathrm{Na}^{+}-\mathrm{SO}_{4}^{2-}-\mathrm{NO}_{3}^{-}-\mathrm{Cl}^{-}-\mathrm{H}_{2} \mathrm{O}$ aerosols, Atmos. Chem. Phys., 7, 4639-4659, https://doi.org/10.5194/acp-74639-2007, 2007.

Garaga, R., Gokhale, S., and Kota, S. H.: Source apportionment of size-segregated atmospheric particles and the influence of particles deposition in the human respiratory tract in rural and urban locations of north-east India, Chemosphere, 255, 126980, https://doi.org/10.1016/j.chemosphere.2020.126980, 2020.

Gautam, S.: The Influence of COVID-19 on Air Quality in India: A Boon or Inutile, B. Environ. Contam. Tox., 104, 724-726, https://doi.org/10.1007/s00128-020-02877-y, 2020.

Gawhane, R. D., Rao, P. S. P., Budhavant, K. B., Waghmare, V., Meshram, D. C., and Safai, P. D.: Seasonal variation of chemical composition and source apportionment of $\mathrm{PM}_{2.5}$ in Pune, India, Environ. Sci. Pollut. Res., 24, 21065-21072, https://doi.org/10.1007/s11356-017-9761-3, 2017.

Guenther, A. B., Jiang, X., Heald, C. L., Sakulyanontvittaya, T., Duhl, T., Emmons, L. K., and Wang, X.: The Model of Emissions of Gases and Aerosols from Nature version 2.1 (MEGAN2.1): an extended and updated framework for modeling biogenic emissions, Geosci. Model Dev., 5, 1471-1492, https://doi.org/10.5194/gmd-5-1471-2012, 2012.

Guo, H., Kota, S. H., Sahu, S. K., Hu, J., Ying, Q., Gao, A., and Zhang, H.: Source apportionment of $\mathrm{PM}_{2.5}$ in North India using source-oriented air quality models, Environ. Pollut., 231, 426436, https://doi.org/10.1016/j.envpol.2017.08.016, 2017.

Gurjar, B. R., Ravindra, K., and Nagpure, A. S.: Air pollution trends over Indian megacities and their localto-global implications, Atmos. Environ., 142, 475-495, https://doi.org/10.1016/j.atmosenv.2016.06.030, 2016.

Guttikunda, S. K., Nishadh, K. A., Gota, S., Singh, P., Chanda, A., Jawahar, P., and Asundi, J.: Air quality, emissions, and source contributions analysis for the Greater Bengaluru region of India, Atmos. Pollut. Res., 10, 941-953, https://doi.org/10.1016/j.apr.2019.01.002, 2019.

Hu, J., Wu, L., Zheng, B., Zhang, Q., He, K., Chang, Q., Li, X., Yang, F., Ying, Q., and Zhang, H.: Source contributions and regional transport of primary particulate matter in China, Environ. Pollut., 207, 31-42, https://doi.org/10.1016/j.envpol.2015.08.037, 2015.

Hu, J., Chen, J., Ying, Q., and Zhang, H.: One-year simulation of ozone and particulate matter in China using WRF/CMAQ 
modeling system, Atmos. Chem. Phys., 16, 10333-10350, https://doi.org/10.5194/acp-16-10333-2016, 2016.

Isaifan, R. J.: The dramatic impact of Coronavirus outbreak on air quality: Has it saved as much as it has killed so far?, Global J. Environ. Sci. Manage., 6, 275-288, https://doi.org/10.22034/gjesm.2020.03.01, 2020.

Jain, S., Sharma, S. K., Vijayan, N., and Mandal, T. K.: Seasonal characteristics of aerosols $\left(\mathrm{PM}_{2.5}\right.$ and $\left.\mathrm{PM}_{10}\right)$ and their source apportionment using PMF: A four year study over Delhi, India, Environ. Pollut., 262, 114337, https://doi.org/10.1016/j.envpol.2020.114337, 2020.

Kabiraj, S. and Gavli, N. V.: Impact of SARS-CoV-2 Pandemic Lockdown on Air Quality Using Satellite Imagery with Ground Station Monitoring Data in Most Polluted City Kolkata, India, Aerosol Sci. Eng., 4, 320-330, 10.1007/s41810-020-00077-z, 2020.

Karambelas, A., Holloway, T., Kiesewetter, G., and Heyes, C.: Constraining the uncertainty in emissions over India with a regional air quality model evaluation, Atmos. Environ., 174, 194-203, https://doi.org/10.1016/j.atmosenv.2017.11.052, 2018.

Kitayama, K., Morino, Y., Yamaji, K., and Chatani, S.: Uncertainties in $\mathrm{O}_{3}$ concentrations simulated by CMAQ over Japan using four chemical mechanisms, Atmos. Environ., 198, 448-462, https://doi.org/10.1016/j.atmosenv.2018.11.003, 2019.

Kota, S. H., Guo, H., Myllyvirta, L., Hu, J., Sahu, S. K., Garaga, R., Ying, Q., Gao, A., Dahiya, S., Wang, Y., and Zhang, H.: Year-long simulation of gaseous and particulate air pollutants in India, Atmos. Environ., 180, 244-255, https://doi.org/10.1016/j.atmosenv.2018.03.003, 2018.

Kroll, J. H., Heald, C. L., Cappa, C. D., Farmer, D. K., Fry, J. L., Murphy, J. G., and Steiner, A. L.: The complex chemical effects of COVID-19 shutdowns on air quality, Nat. Chem., 12, 777779, https://doi.org/10.1038/s41557-020-0535-z, 2020.

Kumar, P., Hama, S., Omidvarborna, H., Sharma, A., Sahani, J., Abhijith, K. V., Debele, S. E., Zavala-Reyes, J. C., Barwise, Y., and Tiwari, A.: Temporary reduction in fine particulate matter due to 'anthropogenic emissions switch-off' during COVID19 lockdown in Indian cities, Sustain. Cities Soc., 62, 102382, https://doi.org/10.1016/j.scs.2020.102382, 2020.

Kumar, S.: Effect of meteorological parameters on spread of COVID-19 in India and air quality during lockdown, Sci. Total Environ., 745, 141021, https://doi.org/10.1016/j.scitotenv.2020.141021, 2020.

Kumari, P., and Toshniwal, D.: Impact of lockdown measures during COVID-19 on air quality - A case study of India, Int. J. Environ. Health Res., https://doi.org/10.1080/09603123.2020.1778646, in press, 2020.

Lal, S., Venkataramani, S., Naja, M., Kuniyal, J. C., Mandal, T. K., Bhuyan, P. K., Kumari, K. M., Tripathi, S. N., Sarkar, U., Das, T., Swamy, Y. V., Gopal, K. R., Gadhavi, H., and Kumar, M. K. S.: Loss of crop yields in India due to surface ozone: an estimation based on a network of observations, Environ. Sci. Pollut. Res., 24, 20972-20981, https://doi.org/10.1007/s11356-0179729-3, 2017.

Le, T., Wang, Y., Liu, L., Yang, J., Yung, Y. L., Li, G., and Seinfeld, J. H.: Unexpected air pollution with marked emission reductions during the COVID-19 outbreak in China, Science, 369, 702-706, https://doi.org/10.1126/science.abb7431, 2020.
Mahajan, A. S., De Smedt, I., Biswas, M. S., Ghude, S., Fadnavis, S., Roy, C., and van Roozendael, M.: Inter-annual variations in satellite observations of nitrogen dioxide and formaldehyde over India, Atmos. Environ., 116, 194-201, https://doi.org/10.1016/j.atmosenv.2015.06.004, 2015.

Mahato, S., Pal, S., and Ghosh, K. G.: Effect of lockdown amid COVID-19 pandemic on air quality of the megacity Delhi, India, Sci. Total Environ., 730, 139086, https://doi.org/10.1016/j.scitotenv.2020.139086, 2020.

Mohan, M. and Gupta, M.: Sensitivity of PBL parameterizations on $\mathrm{PM}_{10}$ and ozone simulation using chemical transport model WRF-Chem over a sub-tropical urban airshed in India, Atmos. Environ., 185, 53-63, https://doi.org/10.1016/j.atmosenv.2018.04.054, 2018.

Mor, S., Kumar, S., Singh, T., Dogra, S., Pandey, V., and Ravindra, K.: Impact of COVID-19 lockdown on air quality in Chandigarh, India: Understanding the emission sources during controlled anthropogenic activities, Chemosphere, 263, 127978, https://doi.org/10.1016/j.chemosphere.2020.127978, 2021.

Mukherjee, K.: COVID-19 and lockdown: Insights from Mumbai, Indian J. Pub. Health, 64, 168-171, https://doi.org/10.4103/ijph.IJPH_508_20, 2020.

Nakada, L. Y. K. and Urban, R. C.: COVID-19 pandemic: Impacts on the air quality during the partial lockdown in Sao Paulo state, Brazil, Sci. Total Environ., 730, 139087, https://doi.org/10.1016/j.scitotenv.2020.139087, 2020.

Oksanen, E., Pandey, V., Pandey, A. K., Keski-Saari, S., Kontunen-Soppela, S., and Sharma, C.: Impacts of increasing ozone on Indian plants, Environ. Pollut., 177, 189-200, https://doi.org/10.1016/j.envpol.2013.02.010, 2013.

Otmani, A., Benchrif, A., Tahri, M., Bounakhla, M., Chakir, E. M., El Bouch, M., and Krombi, M.: Impact of Covid19 lockdown on $\mathrm{PM}_{10}, \mathrm{SO}_{2}$ and $\mathrm{NO}_{2}$ concentrations in Sale City (Morocco), Sci. Total Environ., 735, 139541, https://doi.org/10.1016/j.scitotenv.2020.139541, 2020.

Pai, C., Bhaskar, A., and Rawoot, V.: Investigating the dynamics of COVID-19 pandemic in India under lockdown, Chaos Soliton. Fract., 138, 109988, https://doi.org/10.1016/j.chaos.2020.109988, 2020.

Palmer, P. I., Jacob, D. J., Fiore, A. M., Martin, R. V., Chance, K., and Kurosu, T. P.: Mapping isoprene emissions over North America using formaldehyde column observations from space, J. Geophys. Res.-Atmos., 108, 4180, https://doi.org/10.1029/2002JD002153, 2003.

Purohit, P., Amann, M., Kiesewetter, G., Rafaj, P., Chaturvedi, V., Dholakia, H. H., Koti, P. N., Klimont, Z., BorkenKleefeld, J., Gomez-Sanabria, A., Schopp, W., and Sander, R.: Mitigation pathways towards national ambient air quality standards in India, Environ. Int., 133, 105147 , https://doi.org/10.1016/j.envint.2019.105147, 2019.

Reuters, S. V.: UPDATE 1 - India's March Electricity Usage Falls $9.2 \%$ as Lock-Down Bites, available at: https://uk.reuters.com/article/india-electricity-supply/update1-indias-march-electricity-usage-falls-9-2-as-lockdown, last access: 26 August 2020.

Sahu, S. K., Sharma, S., Zhang, H., Chejarla, V., Guo, H., $\mathrm{Hu}$, J., Ying, Q., Xing, J., and Kota, S. H.: Estimating ground level $\mathrm{PM}_{2.5}$ concentrations and associated health risk in India using satellite based AOD and WRF pre- 
dicted meteorological parameters, Chemosphere, 255, 126969, https://doi.org/10.1016/j.chemosphere.2020.126969, 2020.

Schnell, J. L., Naik, V., Horowitz, L. W., Paulot, F., Mao, J., Ginoux, P., Zhao, M., and Ram, K.: Exploring the relationship between surface PM2.5 and meteorology in Northern India, Atmos. Chem. Phys., 18, 10157-10175, https://doi.org/10.5194/acp-1810157-2018, 2018.

Selvam, S., Muthukumar, P., Venkatramanan, S., Roy, P. D., Manikanda Bharath, K., and Jesuraja, K.: SARS-CoV-2 pandemic lockdown: Effects on air quality in the industrialized Gujarat state of India, Sci. Total Environ., 737, 140391, https://doi.org/10.1016/j.scitotenv.2020.140391, 2020.

Sharma, S., Chatani, S., Mahtta, R., Goel, A., and Kumar, A.: Sensitivity analysis of ground level ozone in India using WRF-CMAQ models, Atmos. Environ., 131, 29-40, https://doi.org/10.1016/j.atmosenv.2016.01.036, 2016.

Sharma, S., Zhang, M., Anshika, Gao, J., Zhang, H., and Kota, S. H.: Effect of restricted emissions during COVID19 on air quality in India, Sci. Total Environ., 728, 138878, https://doi.org/10.1016/j.scitotenv.2020.138878, 2020.

Shehzad, K., Sarfraz, M., and Shah, S. G. M.: The impact of COVID-19 as a necessary evil on air pollution in India during the lockdown, Environ. Pollut., 266, 115080, https://doi.org/10.1016/j.envpol.2020.115080, 2020.

Sicard, P., De Marco, A., Agathokleous, E., Feng, Z., Xu, X., Paoletti, E., Rodriguez, J. J. D., and Calatayud, V.: Amplified ozone pollution in cities during the COVID-19 lockdown, Sci. Total Environ., 735, 139542, https://doi.org/10.1016/j.scitotenv.2020.139542, 2020.

Sillman, S.: The use of $\mathrm{NO}_{y}, \mathrm{H}_{2} \mathrm{O}_{2}$, and $\mathrm{HNO}_{3}$ as indicators for ozone- $\mathrm{NO}_{x}$-hydrocarbon sensitivity in urban locations, J. Geophys. Res.-Atmos., 100, 14175-14188, https://doi.org/10.1029/94JD02953, 1995.

Sillman, S. and He, D.: Some theoretical results concerning $\mathrm{O}_{3}-\mathrm{NO}_{x}$-VOC chemistry and NOx-VOC indicators, J. Geophys. Res.-Atmos., 107, ACH 26-21-ACH 26-15, https://doi.org/10.1029/2001JD001123, 2002.

Srivastava, S., Kumar, A., Bauddh, K., Gautam, A. S., and Kumar, S.: 21-Day Lockdown in India Dramatically Reduced Air Pollution Indices in Lucknow and New Delhi, India, B. Environ. Contam. Tox., 105, 9-17, https://doi.org/10.1007/s00128020-02895-w, 2020.
Steiner, A. L., Cohen, R. C., Harley, R. A., Tonse, S., Millet, D. B., Schade, G. W., and Goldstein, A. H.: VOC reactivity in central California: comparing an air quality model to ground-based measurements, Atmos. Chem. Phys., 8, 351-368, https://doi.org/10.5194/acp-8-351-2008, 2008.

Wang, D., Hu, J., Xu, Y., Lv, D., Xie, X., Kleeman, M., Xing, J., Zhang, H., and Ying, Q.: Source contributions to primary and secondary inorganic particulate matter during a severe wintertime $\mathrm{PM}_{2.5}$ pollution episode in Xi'an, China, Atmos. Environ., 97, 182-194, https://doi.org/10.1016/j.atmosenv.2014.08.020, 2014.

Wang, P., Chen, K., Zhu, S., Wang, P., and Zhang, H.: Severe air pollution events not avoided by reduced anthropogenic activities during COVID-19 outbreak, Resour. Conserv. Recy., 158, 104814, https://doi.org/10.1016/j.resconrec.2020.104814, 2020.

WHO: Global urban ambient air pollution database (update 2016), available at: http://www.who.int/phe/health_topics/outdoorair/ databases/cities/en/, (last access: 27 August 2020), 2016.

WHO: WHO Global Ambient Air Quality Database (Update 2018), available at: http://www.who.int/airpollution/data/cities/en/ (last access: 27 August 2020), 2018.

Wiedinmyer, C., Akagi, S. K., Yokelson, R. J., Emmons, L. K., AlSaadi, J. A., Orlando, J. J., and Soja, A. J.: The Fire INventory from NCAR (FINN): a high resolution global model to estimate the emissions from open burning, Geosci. Model Dev., 4, 625641, https://doi.org/10.5194/gmd-4-625-2011, 2011.

Zhang, H., Wang, Y., Hu, J., Ying, Q., and Hu, X. M.: Relationships between meteorological parameters and criteria air pollutants in three megacities in China, Environ. Res., 140, 242-254, https://doi.org/10.1016/j.envres.2015.04.004, 2015.

Zhang, Q., Shao, M., Li, Y., Lu, S. H., Yuan, B., and Chen, W. T.: Increase of ambient formaldehyde in Beijing and its implication for VOC reactivity, Chinese Chem. Lett., 23, 1059-1062, https://doi.org/10.1016/j.cclet.2012.06.015, 2012.

Zhao, B., Wu, W., Wang, S., Xing, J., Chang, X., Liou, K.-N., Jiang, J. H., Gu, Y., Jang, C., Fu, J. S., Zhu, Y., Wang, J., Lin, Y., and Hao, J.: A modeling study of the nonlinear response of fine particles to air pollutant emissions in the BeijingTianjin-Hebei region, Atmos. Chem. Phys., 17, 12031-12050, https://doi.org/10.5194/acp-17-12031-2017, 2017. 